\begin{tabular}{lccc} 
VERSITA & GOSPODARKA & SUROWCAMI & MINERALNYMI \\
\hline \multirow{2}{*}{ Tom 29} & 2013 & Zeszyt 1 \\
& & DOI 10.2478/gospo-2013-0005 &
\end{tabular}

\title{
Optimal site selection for heap leaching structures by the analytic hierarchy process (case study: Taft heap leaching structure, Iran)
}

\section{Introduction}

To construct heap leaching structures, a vast area in the range of hundreds of thousands of $\mathrm{m}^{2}$ is selected. This area is leveled, longitudinally and transversely, in such a way that the final foundation surface will consist of one or more valleys with a common exit and a smooth slope of 5 to 10 percent. This foundation is covered with one or more layers of compacted composite soil, compacted natural clay, or a geo-synthetic clay layer (GCL). The main isolation layer, which is the geo-membrane, is then laid on the top. To protect the top geo-membrane layer, a 20 to $30 \mathrm{~cm}$ thick soil layer (consisting mostly of sand) is placed over it. The structure's drainage system, which is a combination of slotted polyethylene pipes and a gravelly drainage layer, is installed on the sandy soil (Majdi et al. 2007; Majdi et al. 2009; Giroud et el. 2001). To prevent the clogging of the system, a layer of filter is placed over the drainage. This last layer is then covered with mineral soil in steps from 5 to 15 meters in height. Then, a proper solvent (e.g. sulfuric acid for copper) is dripped over the mineral step (Smith, Zhao 2004; Thiel, Smith 2004). The acid fluid passes through the mineral soils under its own weight and, while moving, dissolves the objective mineral existing in the soil (Kampf et el. 2002). The solvate containing the objective mineral is directed outwards gravitationally through the drainage system and sent to the leaching complex. It is transferred back over the heap for rewashing after the mineral in question has been extracted (Fig. 1).

* Department of mining engineering, University of Kashan, Iran; e-mail: saeedsoltani@kashanu.ac.ir

** Department of mining engineering, Tehran University, Iran. 
The heap leach pad site should be selected to minimize the costs of slope leveling, borrow materials haulage, earth work, purchase and installation of the geo-synthetic and, in the meantime, to keep negative environmental effects within allowable limits. Generally, different sites are proposed for a heap construction, and the selection of the optimum alternative is very important.

In this research, different technical, financial, construction, environmental, and time criteria affecting the selection of a heap leach pad site were taken into account. The interrelations between these criteria are quite complicated and usually one affects another; therefore, making a model and finding a site using independent criteria is not an easy task (Peniwati 2007), making the use of multi-criteria decision making (MCDM) techniques quite helpful. There are different MCDM techniques (weighting-sum, Topsis, Electre, AHP, etc.)

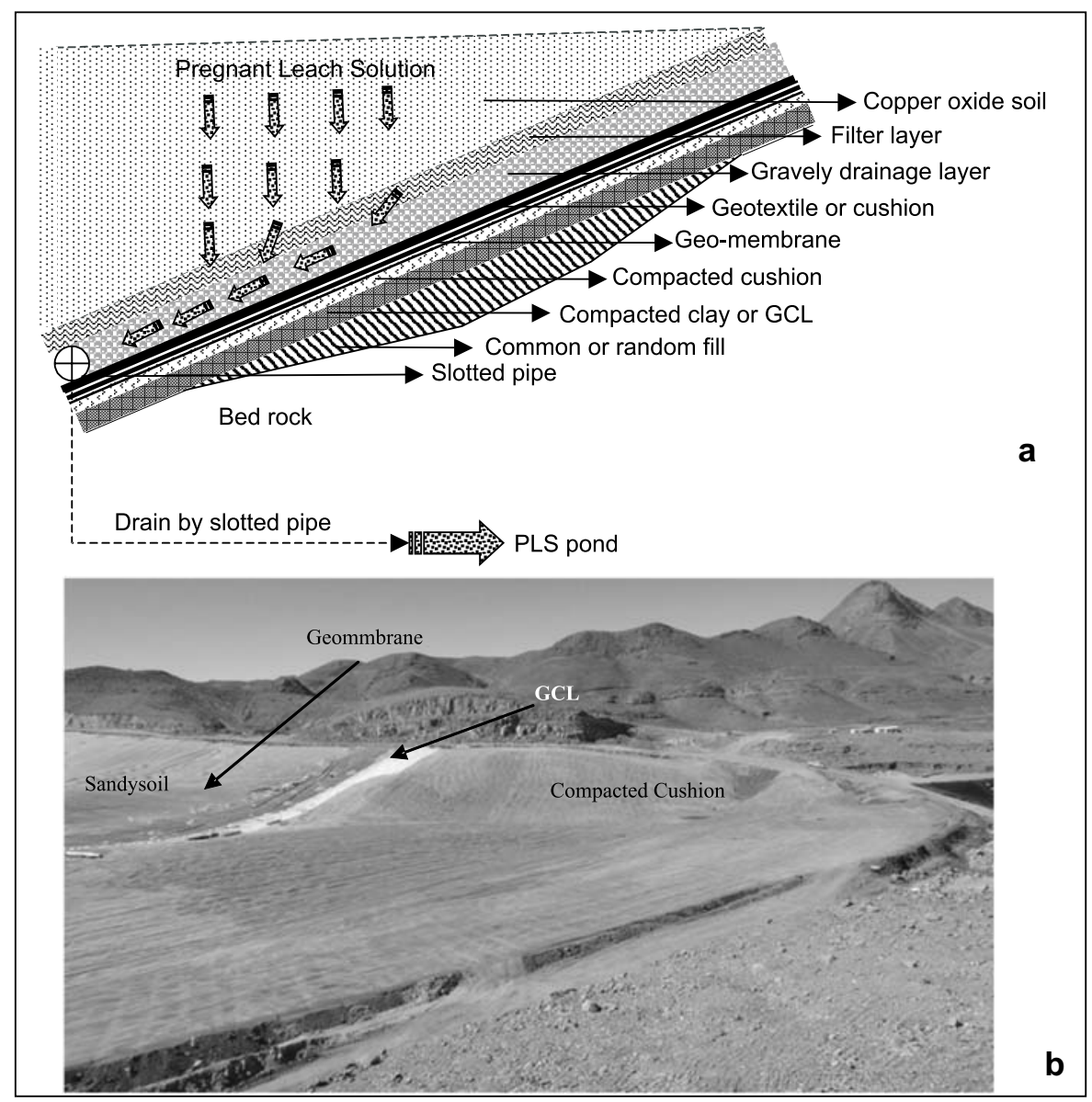

Fig. 1. Construction of the foundation of a heap leaching structure a) schematic; b) real

Rys. 1. Przekrój i widok hałdy do ługowania a) schemat; b) rzeczywistość 
among which the Analytic hierarchy process (AHP) is capable of considering technical and environmental criteria while giving the same importance to the financial and time criteria in selecting the optimum heap leach pad site location.

\section{Criteria affecting the heap leach pad site selection}

\subsection{Topography (Topo)}

The topography of a potential site for heap leaching facilities is an important factor during the selection process. The final bed slope should be from 2 to 10 percent so that it can direct the existing fluid (throughout the drainage system) towards the head wall. In steep slopes (more than 10 percent), there is a probability of the mineral heap sliding, and installation of cushions and gravel over the geo-membrane liner becomes very difficult. In slopes of less than 2 percent, the flow of the fluid through gravel is restricted.

\subsection{Haulage distance (HD)}

Since mineral materials should be transferred from the dump or the mine to the heap leach facility, the pad site should preferably have the least haulage distance from these sources. But, since haulage of the mineral soils to the heap continues throughout the exploitation period, it does not affect the initial investment or the heap construction time.

\subsection{Construction materials sources (CMS)}

A major portion of the heap construction time and costs is related to the construction of natural bed layers (consisting of clay, sandy soil, gravel, and filter); therefore, proximity to construction material sources is quite important both economically and chronologically.

$$
\text { 2.4. Hydrology (Hydr) }
$$

The heap leach pad site preferably should not lie on the course of surface and torrential waters; otherwise, it is necessary that these waters be appropriately directed around the heap area by constructing canals or berms.

\subsection{Hy drog e ology (Hydro)}

If, by any chance, the geo-membrane liner is punctured, it is probable that the acid fluid would penetrate into the ground. After penetration, this fluid enters the underground water and pollutes it. Therefore, the lower the underground water surface and the lesser the connection between the heap subsurface water and springs, aqueducts, drinking, and agricultural waters, the more appropriate will be the heap leach pad site. 


\subsection{Geological study (GS)}

Another point worth considering in the selection of a heap leach pad site is the geological characteristics of the heap foundation (alluvial soils, rock type, joints, discontinuities, etc.). The better the quality of the rock mass of a foundation, the more appropriate the site will be because it is less permeable to probable acid infiltration. Also, carbonated rock masses have priority for a heap bed because they cause dissolution and neutralization of acid which penetrates into the ground.

\subsection{Surrounding structures}

Although the stability of the heap leach facility is inspected and confirmed, sliding of the polluted mineral heap is quite possible due to some force majeure. Therefore, it is necessary that the heap leach pad be located where a probable slide would not seriously affect susceptible structures.

\subsection{Geotechnical parameters (GeotS)}

The heap foundation should have a proper loading capacity; its liquefaction, Karstic, or artesian potential too should be zero. Therefore, it is necessary that the geotechnical specifications of the bed be taken into account.

\subsection{Vegetation}

The heap foundation should lack any vegetation; it is necessary that the bed be dug to about 50 centimeters and the vegetated soil be transferred to other places. Grass growth on the heap foundation will cause damage to the geo-membrane liner and penetration of acid through to the ground. Therefore, the lesser the initial vegetation on the heap leach pad site the more appropriate it will be.

\section{Degree of importance of the parameters affecting the heap leach pad site selection}

To determine the optimum heap leach pad site, some preliminary alternatives are considered and their specifications are gathered. The best alternative is then specified by comparing their positive and negative points. But, as mentioned earlier, the variety and degree of importance of the parameters do not allow a straightforward selection of the heap leach pad site. Their comparison is difficult and complicated too. Based on our team's experiences in the design, execution, and exploitation of eight successful heap pad facilities and considering the financial, chronological, and environmental factors, the degree of importance of every parameter for the selection of the heap leach pad site is proposed in the form of Table 1. 
Degree of importance of criteria for heap leach pad site selection

Stopień wpływu kryteriów na wybór miejsc ługowania

\begin{tabular}{|l|l|l|l|l|l|}
\hline \multicolumn{1}{|c|}{ Criteria } & Very low & Low & Average & High & Very high \\
\hline \hline Topography & & & & & \\
\hline Haulage distance & & & & & \\
\hline Borrow sources & & & & & \\
\hline Hydrology & & & & & \\
\hline Hydrogeology & & & & & \\
\hline Geological characteristics & & & & & \\
\hline Surrounding structures & & & & & \\
\hline Geotechnical parameters & & & & & \\
\hline Vegetation & & & & & \\
\hline
\end{tabular}

\section{Locating the optimum heap leach pad site using AHP}

Locating, in earth sciences, is when an expert exchanges ideas (requirements, objectives, and information regarding the existing situation) with other specialists, reconsiders his needs and objectives according to the new information, and tries to select the best option from among the existing alternatives for the application he has in mind. Proper and optimum locating is possible when the researcher can properly, logically, and scientifically relate the information obtained from other related specialists considering the alternatives and priorities. Since the parameters and criteria are numerous and play varying roles in locating a site, contemporary efforts at site selection are conducted more scientifically and logically using multi-criteria decision making (MCDM) methods such as the analytical hierarchical process (AHP). This is a flexible, powerful, and simple method used when making a decision among different alternatives becomes difficult due to the presence of contradicting criteria. In the present research, use has been made of AHP (from among different MCDM methods) because of the following reasons:

1. This is the only method that can evaluate the consistency of the judgments of decision makers; it takes advantage of quantitative as well as qualitative criteria for decision making.

2. Pair wise comparison in AHP lets decision makers extract the weight of the criteria or the order of the alternatives from the pair wise comparison matrixes; many criteria can be taken into account. 
3. AHP helps decision makers to enter the critical aspects of the problem in a hierarchical structure and make them flexible (Mahmoodzadeh et al. 2007).

4. The AHP model solves complex decision making problems by putting the alternatives in a hierarchical structure which is created through pair wise comparison of independent judgments; therefore, compared with other models that simultaneously prioritize all the decisions and the criteria, it is preferable (Saaty 1980).

AHP normally consists of the following seven steps (Lee et al. 2008; Hosseinali, Alesheikh 2008):

- Definition of the criteria affecting decision making.

- Formation of the hierarchical structure.

- Application of pair-wise comparison between decision making criteria for the creation of the comparison matrix.

- Using the eigenvector method to find the relative weights of the decision making criteria.

- Controlling the inconsistency of the pair-wise comparison matrixes.

- Collecting the weighted criteria to determine the final grading of the alternatives.

- Sensitivity analysis.

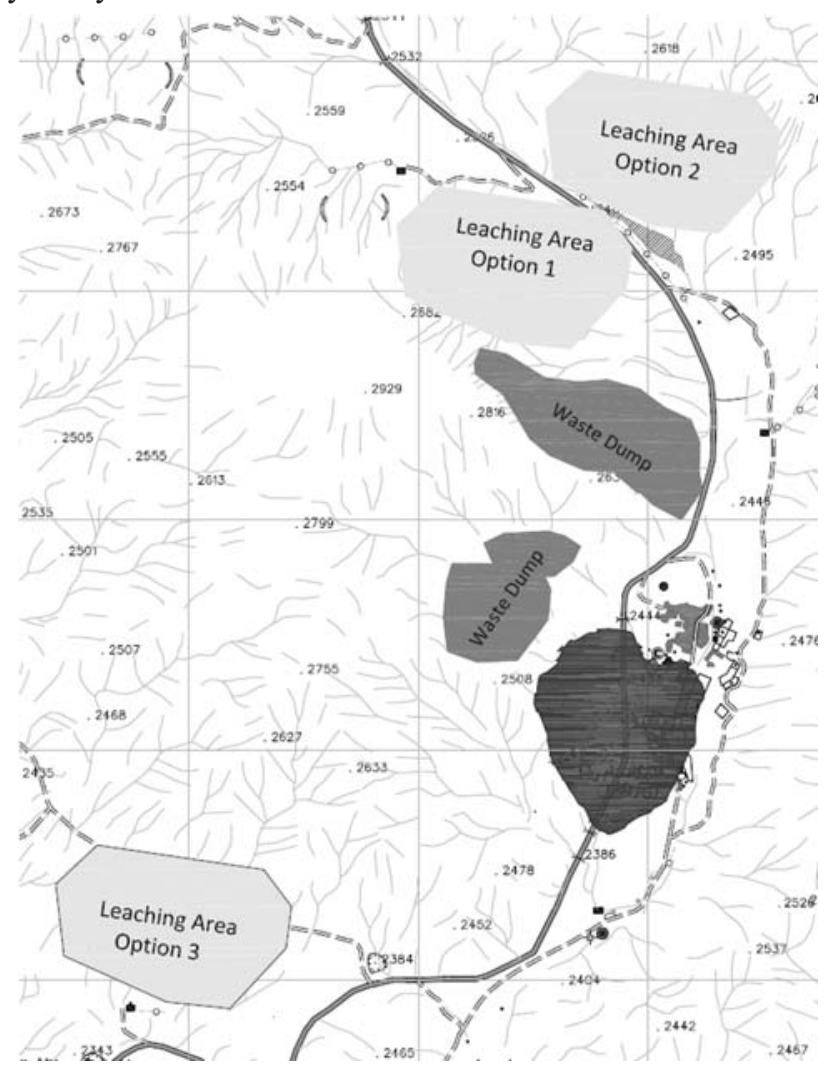

Fig. 2. Situation of the suggested sites for the heap leaching structure Rys. 2. Propozycja lokalizacji miejsc ługowania 
These steps have been followed and the results used in locating appropriate sites for the heap structure.

\section{Locating the optimum site for Taft heap leaching structure using AHP}

\subsection{Taft heap leaching structure}

The Ali-Abad and Zereshk-darreh copper mines near Yazd province, Iran, are situated $3 \mathrm{~km}$ from each other. Their total copper oxide reserves are 32 million tons. The Ali-Abad mine, near Ali-Abad city, is close to agricultural farms. Thus, to prevent the destruction of and acid infiltration into the farms, a common leaching factory with a nominal capacity of 3,000 ton/year of pure copper was designed near the Zereshk-darreh mine to recover copper from the reserves. Due to land ownership limitations, the consulting company proposed 3 preliminary sites for the factory. The design team was to select the optimum alternative from among the 3 proposals and identify the site of the factory. Fig. 2 shows the locations of the proposed alternatives with respect to the Zereshk-darreh copper mine. Alternatives I and II are closer to Ali-Abad, but III is at a farther distance from this mine.

\subsection{Some information about \\ the suggested preliminary sites}

To start with in considering site selection criteria, preliminary information regarding the suggested sites was gathered and the locations qualitatively compared with one another. The results of this comparison are given in Table 2. In this table, the reasons for the priority of each alternative with respect to the next are stated descriptively.

\subsection{Using AHP to determine the optimum site}

The basic AHP evaluating model for the selection of the optimum location of the Taft heap leaching facility can be formed according to the following steps:

Step 1 - defining evaluative criteria: various factors such as topography, haulage distance, borrow sources, hydrology, hydrogeology, geological characteristics, surrounding structure, and geotechnical parameters are influential in the selection of the heap leaching facility site (KarimiNasab et al. 2007).

Step 2 - forming the hierarchical structure: the decision hierarchy consists of the decision objective, criteria, and alternatives. Here, locating the heap leach pad site is the decision objective, different evaluative factors are criteria, and the 3 locations suggested for the heap leach pad site are the decision alternatives. Since the maximum acceptable number of parameters in AHP is $7 \pm 2$, all the criteria have been considered as those necessary for prioritization. Fig. 3 shows the hierarchal structure. 
Comparison of the suggested sites for heap construction

Porównanie proponowanych lokalizacji miejsca ługowania hałdy

\begin{tabular}{|c|c|c|c|l|}
\hline \multirow{2}{*}{ Criteria } & \multicolumn{2}{|c|}{ Alternatives } & \multicolumn{2}{c|}{ Description } \\
\cline { 2 - 4 } Topography & I & II & III & \\
\hline \hline Hydrology & & & $\times$ & $\begin{array}{l}\text { Alternative III topography slope is approximately } 5 \text { to } \\
10 \text { percent and naturally drains downward. Thus, earthwork } \\
\text { is very limited and it is superior to alternatives I and II }\end{array}$ \\
\hline $\begin{array}{c}\text { Hydrogeology } \\
\text { Geology }\end{array}$ & $\times$ & $\times$ & $\begin{array}{l}\text { Alternatives I and II are situated in the course of many } \\
\text { waterways that need controlling. Alternative III on the other } \\
\text { hand, is not in the course of any torrential or surface water }\end{array}$ \\
\hline $\begin{array}{c}\text { Distance from } \\
\text { the source }\end{array}$ & $\times$ & $\times$ & $\times$ & $\begin{array}{l}\text { Alternative II is situated directly over aqueducts and } \\
\text { underground waters. It is, therefore, a serious threat for } \\
\text { agricultural waters. Alternatives I and III, on the other hand, } \\
\text { are on rocky foundations, far from the area aqueducts }\end{array}$ \\
\hline $\begin{array}{c}\text { Borrow } \\
\text { sources }\end{array}$ & $\times$ & $\times$ & $\times$ & $\begin{array}{l}\text { The foundation material of alternative I is limestone which } \\
\text { causes neutralization of the infiltrated acid }\end{array}$ \\
\hline $\begin{array}{c}\text { Surrounding } \\
\text { structures }\end{array}$ & & $\times$ & $\begin{array}{l}\text { The haulage distance from the Ali-Abad mine to alternative } \\
\text { III is 4 km more than that of the other alternatives }\end{array}$ \\
\hline $\begin{array}{c}\text { Geotechnical } \\
\text { studies }\end{array}$ & $\times$ & $\times$ & $\begin{array}{l}\text { Distances from construction materials sources to alternatives } \\
\text { I and II are the same and less than that of alternative III }\end{array}$ \\
\hline
\end{tabular}

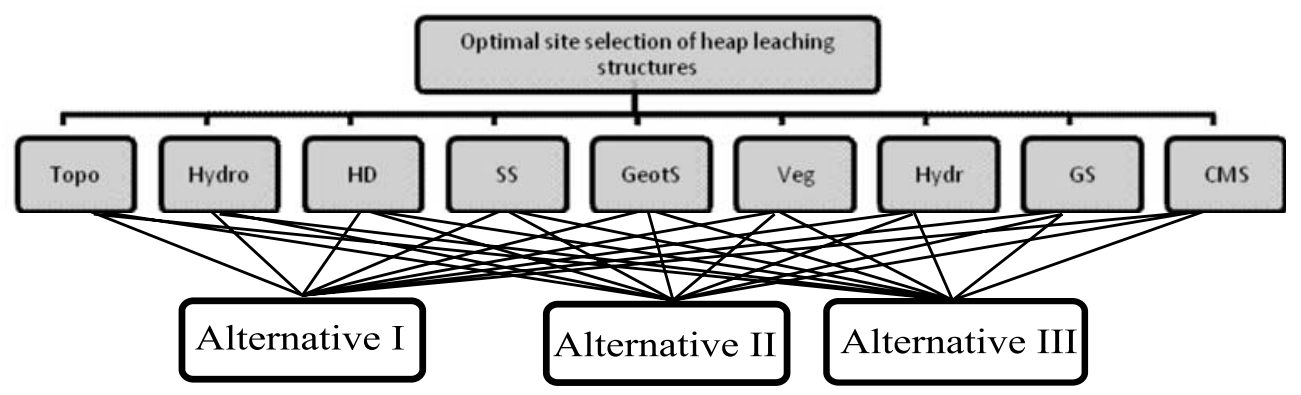

Fig. 3. Hierarchical structure to select and evaluate the optimal location for heap leaching pad site with respect to competitive advantages

Rys. 3. Wybór i ocena optymalnej lokalizacji ługowania za pomocą analizy hierarchicznej 
Step 3 - establishing the pair-wise comparison matrix: AHP is based on pair-wise comparisons which create a basis for the determination of alternatives. Pair-wise comparisons were carried out by an expert team consisting of 1) a mining engineer with 25 years of experience in the copper industry as the project manager; 2) a mineral processing engineer with 8 years of experience in the leaching industry; and 3) a geotechnical

TABLE 3

Pair-wise comparison scale for AHP preferences (Saaty, Luis 199)

TABELA 3

Skala porównania parami do wyboru AHP

\begin{tabular}{||l|c|}
\hline \multicolumn{1}{|c|}{ Verbal judgments of preferences } & Numerical rating \\
\hline \hline Extremely preferred & 9 \\
\hline Very strongly to extremely & 7 \\
\hline Very strongly & 6 \\
\hline Strongly to very strongly & 5 \\
\hline Strongly preferred & 4 \\
\hline Moderately to strongly & 3 \\
\hline Moderately preferred & 2 \\
\hline Equally to moderately & 1 \\
\hline Equally preferred & \\
\hline
\end{tabular}

TABLE 4

Aggregate pair-wise comparison matrix for criteria

TABELA 4

Zagregowana macierz porównania kryteriów parami

\begin{tabular}{|l|c|c|c|c|c|c|c|c|c|}
\hline & Topo & Hydrg & HD & FS & GeotS & EC & Hydr & GS & BS \\
\hline \hline Topo & 1.00 & 5.00 & 1.00 & 7.00 & 8.00 & 3.00 & 3.00 & 7.00 & 1.00 \\
\hline Hydrg & 0.20 & 1.00 & 0.14 & 3.00 & 1.00 & 5.00 & 2.00 & 2.00 & 0.33 \\
\hline HD & 1.00 & 7.00 & 1.00 & 5.00 & 5.00 & 3.00 & 5.00 & 7.00 & 1.00 \\
\hline FS & 0.14 & 0.33 & 0.20 & 1.00 & 1.00 & 0.33 & 1.00 & 1.00 & 0.20 \\
\hline GeotS & 0.13 & 1.00 & 0.20 & 1.00 & 1.00 & 0.33 & 1.00 & 1.00 & 0.20 \\
\hline EC & 0.33 & 0.20 & 0.33 & 3.00 & 3.00 & 1.00 & 3.00 & 3.00 & 0.50 \\
\hline Hydr & 0.33 & 0.50 & 0.20 & 1.00 & 1.00 & 0.33 & 1.00 & 1.00 & 0.20 \\
\hline GS & 0.14 & 0.50 & 0.14 & 1.00 & 1.00 & 0.33 & 1.00 & 1.00 & 0.17 \\
\hline BS & 1.00 & 3.00 & 1.00 & 5.00 & 5.00 & 2.00 & 5.00 & 6.00 & 1.00 \\
\hline \multicolumn{70}{|c|}{$\lambda_{\text {max }}=9.75 ; \mathrm{CI}=0.09 ; \mathrm{RI}=1.54 ; \mathrm{CR}=0.06$} & \\
\hline
\end{tabular}


Compare the relative preference with respect to: Topo

TABELA 5

Porównanie względnej preferencji w odniesieniu do: Topo

\begin{tabular}{||c|c|c|c||}
\hline \hline & $\mathrm{A}$ & $\mathrm{B}$ & $\mathrm{C}$ \\
\hline \hline $\mathrm{A}$ & 1 & 0.2 & 0.11 \\
\hline $\mathrm{B}$ & 5 & 1.0 & 0.25 \\
\hline $\mathrm{C}$ & 9 & 4.0 & 1.0 \\
\hline \multicolumn{2}{|c|}{$\lambda_{\max }=3.07 ; \mathrm{CI}=0.03 ; \mathrm{RI}=0.66 ; \mathrm{CR}=0.05$} \\
\hline
\end{tabular}

Compare the relative preference with respect to: Hydrg

Porównanie względnej preferencji w odniesieniu do: Hydrg.

\begin{tabular}{|c|c|c|c||}
\hline & $\mathrm{A}$ & $\mathrm{B}$ & $\mathrm{C}$ \\
\hline \hline $\mathrm{A}$ & 1.0 & 5 & 0.33 \\
\hline $\mathrm{B}$ & 0.2 & 1 & 0.11 \\
\hline $\mathrm{C}$ & 3.0 & 9 & 1.0 \\
\hline \multicolumn{4}{|c|}{$\lambda_{\max }=3.03 ; \mathrm{CI}=0.01 ; \mathrm{RI}=0.66 ; \mathrm{CR}=0.01$} \\
\hline
\end{tabular}

Compare the relative preference with respect to: HD

Porównanie względnej preferencji w odniesieniu do: HD

\begin{tabular}{|c|c|c|c||}
\hline & $\mathrm{A}$ & $\mathrm{B}$ & $\mathrm{C}$ \\
\hline \hline $\mathrm{A}$ & 1.0 & 1.0 & 5 \\
\hline $\mathrm{B}$ & 1.0 & 1.0 & 5 \\
\hline $\mathrm{C}$ & 0.2 & 0.2 & 1 \\
\hline \multicolumn{4}{|c||}{$\lambda_{\max }=3 ; \mathrm{CI}=0.0 ; \mathrm{RI}=0.66 ; \mathrm{CR}=0.0$} \\
\hline
\end{tabular}

Compare the relative preference with respect to: FS

Porównanie względnej preferencji w odniesieniu do: FS

\begin{tabular}{|c|c|c|c||}
\hline \hline & $\mathrm{A}$ & $\mathrm{B}$ & $\mathrm{C}$ \\
\hline \hline $\mathrm{A}$ & 1 & 0.2 & 0.14 \\
\hline $\mathrm{B}$ & 5 & 1.0 & 0.33 \\
\hline $\mathrm{C}$ & 7 & 3.0 & 1.0 \\
\hline \multicolumn{4}{|c|}{$\lambda_{\max }=3.06 ; \mathrm{CI}=0.03 ; \mathrm{RI}=0.66 ; \mathrm{CR}=0.04$} \\
\hline
\end{tabular}


Compare the relative preference with respect to: GeotS

Porównanie względnej preferencji w odniesieniu do: GeotS

\begin{tabular}{|c|c|c|c||}
\hline & $\mathrm{A}$ & $\mathrm{B}$ & $\mathrm{C}$ \\
\hline \hline $\mathrm{A}$ & 1.0 & 3 & 0.33 \\
\hline $\mathrm{B}$ & 0.33 & 1 & 0.17 \\
\hline $\mathrm{C}$ & 3.0 & 6 & 1.0 \\
\hline \multicolumn{4}{|c|}{$\lambda_{\max }=3.02 ; \mathrm{CI}=0.01 ; \mathrm{RI}=0.66 ; \mathrm{CR}=0.01$} \\
\hline
\end{tabular}

Compare the relative preference with respect to: EC

TABLE 10

TABELA 10

Porównanie względnej preferencji w odniesieniu do: EC

\begin{tabular}{|c|c|c|c||}
\hline & $\mathrm{A}$ & $\mathrm{B}$ & $\mathrm{C}$ \\
\hline \hline $\mathrm{A}$ & 1.0 & 4 & 0.33 \\
\hline $\mathrm{B}$ & 0.25 & 1 & 0.11 \\
\hline $\mathrm{C}$ & 3.0 & 9 & 1.0 \\
\hline \multicolumn{2}{|c|}{$\lambda_{\max }=3.01 ; \mathrm{CI}=0.005 ; \mathrm{RI}=0.66 ; \mathrm{CR}=0.01$} \\
\hline
\end{tabular}

Compare the relative preference with respect to: Hydr

TABLE 11

TABELA 11

Porównanie względnej preferencji w odniesieniu do: Hydr

\begin{tabular}{|c|c|c|c||}
\hline & $\mathrm{A}$ & $\mathrm{B}$ & $\mathrm{C}$ \\
\hline \hline $\mathrm{A}$ & 1.0 & 7 & 1.0 \\
\hline $\mathrm{B}$ & 0.14 & 1 & 0.14 \\
\hline $\mathrm{C}$ & 1.0 & 7 & 1.0 \\
\hline \multicolumn{3}{|c|}{$\lambda_{\max }=3 ; \mathrm{CI}=0.0 ; \mathrm{RI}=0.66 ; \mathrm{CR}=0.0$} \\
\hline
\end{tabular}

Compare the relative preference with respect to: GS

Porównanie względnej preferencji w odniesieniu do: GS

\begin{tabular}{|c|c|c|c||}
\hline & A & B & C \\
\hline \hline A & 1 & 1 & 0.33 \\
\hline B & 1 & 1 & 0.33 \\
\hline $\mathrm{C}$ & 3 & 3 & 1.0 \\
\hline \multicolumn{4}{|c|}{$\lambda_{\max }=3 ; \mathrm{CI}=0.0 ; \mathrm{RI}=0.66 ; \mathrm{CR}=0.0$} \\
\hline
\end{tabular}


engineer with 10 years of experience in heap leaching construction. First, every team member completed his own pair-wise comparison matrix based on the relative scale measurement shown in Table 3 (Saaty 2000). The final matrix was then formed by averaging and rounding the results of the comparisons made by every member. Pair-wise comparison matrixes of all the criteria are given in Tables 3 to 12 .

Step 4 - using the eigenvector method for the determination of the relative weights of the criteria: In this step, the relative weights of the criteria and alternatives were calculated using the eigenvector method. The calculations were carried out in the "Expert Choice" software (Expert Choice 2000) and the results are shown in Table 13.

TABLE 13

Weights of the 3 alternative sites for heap construction based on the 8-fold criteria, their weights, and the final score of each criterion

TABELA 13

Wagi trzech alternatywnych miejsc ługowania hałdy oparte na 8 kryteriach, ich wagi i wynik z kryterium

\begin{tabular}{|c|c|c|c|c|c|c|c|c|c|c|c|}
\hline & \multicolumn{9}{|c|}{ Criteria (relative weight) } & \multirow[b]{2}{*}{ Total } \\
\hline & & $\begin{array}{c}\text { Topo } \\
(0.24)\end{array}$ & $\begin{array}{c}\text { Hydrg } \\
(0.10)\end{array}$ & $\begin{array}{l}\text { HD } \\
(0.25)\end{array}$ & $\begin{array}{c}\text { FS } \\
(0.03)\end{array}$ & $\begin{array}{c}\text { GeotS } \\
(0.04)\end{array}$ & $\begin{array}{c}\text { EC } \\
(0.08)\end{array}$ & $\begin{array}{l}\text { Hydr } \\
(0.04)\end{array}$ & $\begin{array}{c}\text { GS } \\
(0.03)\end{array}$ & $\begin{array}{c}\text { BM } \\
(0.19)\end{array}$ & \\
\hline \multirow{3}{*}{ Alternatives } & I & 0.06 & 0.27 & 0.46 & 0.07 & 0.25 & 0.25 & 0.47 & 0.20 & 0.43 & 0.32 \\
\hline & II & 0.23 & 0.06 & 0.46 & 0.28 & 0.10 & 0.07 & 0.07 & 0.20 & 0.43 & 0.31 \\
\hline & III & 0.71 & 0.67 & 0.09 & 0.65 & 0.66 & 0.68 & 0.47 & 0.60 & 0.14 & 0.37 \\
\hline
\end{tabular}

Step 5 - testing the consistency of each pair-wise comparison matrix: to control the matrix consistency, use is made of the consistency ratio (CR) which is calculated as follows:

$$
\begin{gathered}
\mathrm{CI}=\frac{\lambda_{\text {max }}-n}{n-1} \\
\mathrm{RI}=\frac{1.98(n-2)}{n} \\
\mathrm{CR}=\mathrm{CI} / \mathrm{RI}
\end{gathered}
$$

where $\mathrm{n}$ is the matrix size, $\lambda_{\max }$ is the highest eigenvalue, $\mathrm{CI}$ is the consistency index, and RI is the random index. The acceptable consistency range in each system will depend on the decision maker. Generally, however, Satty (2000) suggests that if the decision consistency ratio is greater than 0.1 , the decision maker had better revise his judgments. 
Consistency ratios for the conducted pair-wise comparisons are given in Tables 3-10. As shown, the CR of all pair-wise comparison matrixes is less than 0.1 which shows consistency.

Step 6 - selecting the optimum site for heap leaching facility: the score of every Alternative with respect to the different criteria and also the main objective are given in table 11 . As shown, Alternative III has the highest score with respect to the main objective; Alternatives I and II stand after III respectively.

Step 7 - sensitivity analysis for the optimum site selection under different conditions: criteria weights have the highest effect on the grading of the alternatives. The decision maker is to know how trustworthy the results are so that he can make the final decision. Due to the existence of uncertainty in different stages of multi-criteria decision making, it is necessary that sensitivity analysis be carried out on the problem before the final alternative is selected. Sensitivity analysis consists of recalculation of the alternative grading with modification of the weight of every criterion. To do this, the weight of a criterion is increased or decreased gradually (in a situation where the weights of other parameters have remained unchanged). After the sensitivity analysis, grading of the alternatives may vary (Saaty 1990). Sensitivity analysis was done in the "Expert Choice" software (edition 2002). The performance graph (Fig. 4) shows how the alternative priority changes with a change in the importance of a criterion. We studied the sensitivity of the alternative priority under conditions where the weights of topography, haulage distance, and borrow sources criteria change. With a decrease of 24 to 18 percent in the weight of the topography criterion, priorities remained unchanged; then, they changed order to III, II, I (Fig. 5). As shown, if the topography criterion weight decreases from 18 to 13 percent, the new order does not change, but if this weight decreases below

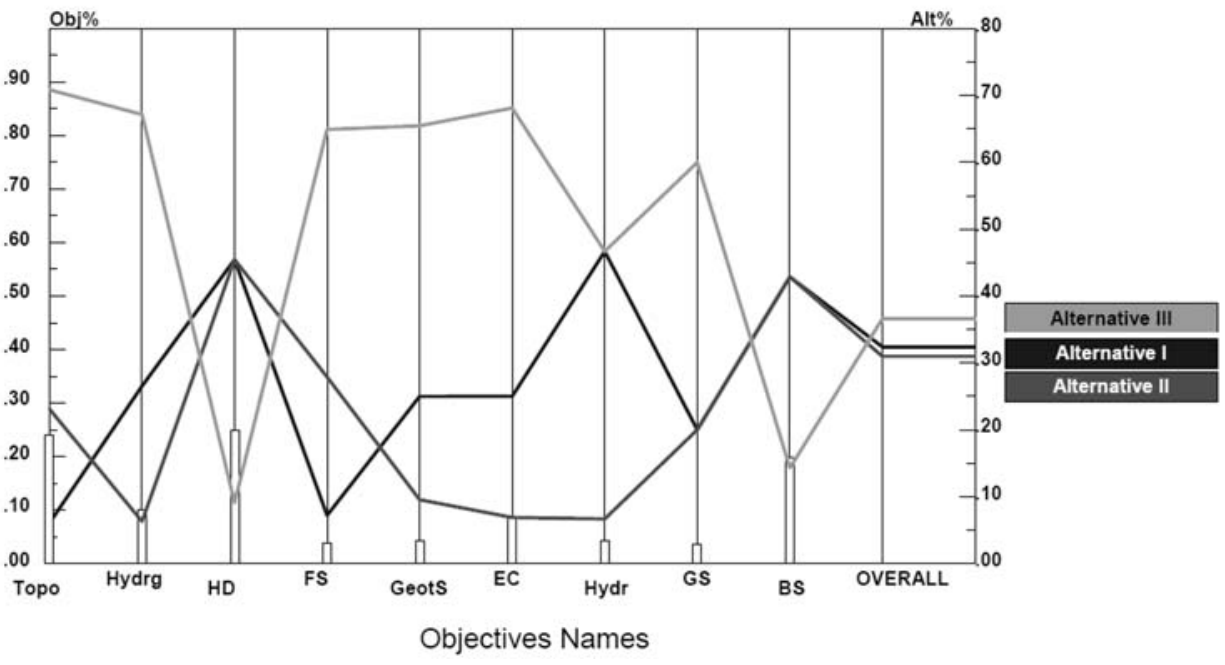

Fig. 4. Alternatives performance sensitivity analyses

Rys. 4. Alternatywne analizy dokładności wyników 
13 percent, the final weight of choice II will become more than that of choice III. Also, with an increase of 19 to 30 percent in the weight of the borrow source criterion, there is a decrease in the final weight of alternative III and an increase in those of alternatives I and II, but grading of the choices remains unchanged. If the increase in the weight of the borrow source is more than 30 percent, the grading will change and I becomes first (Fig. 6); if this weight increases beyond 95 percent, II will substitute I. The initial weight of the haulage distance criterion was 24.5 percent; grading remained unchanged with an increase of up to 33 percent in this weight (Fig. 7).

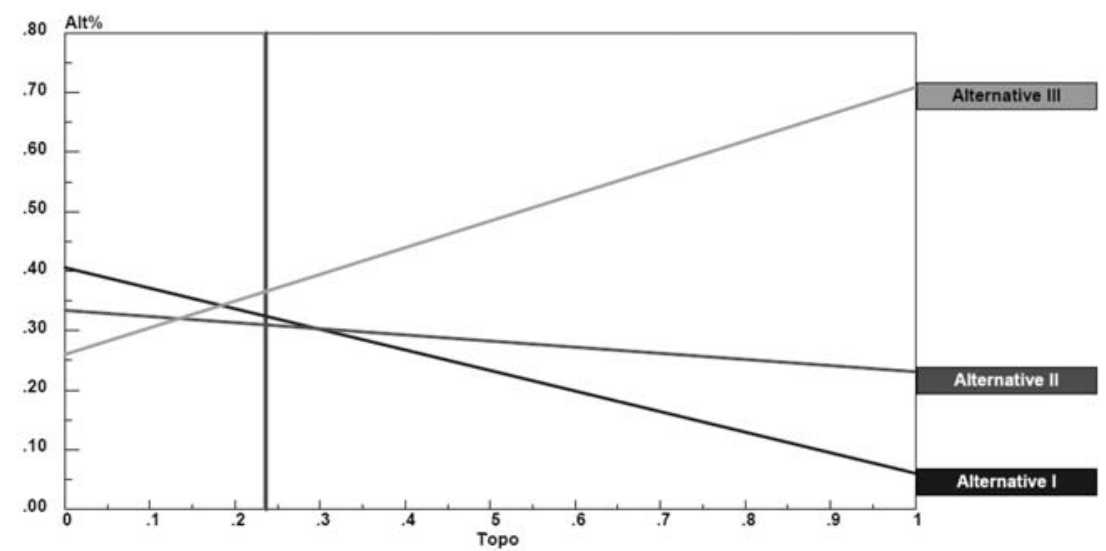

Fig. 5. Gradient sensitivity analysis for Topography criterion

Rys. 5. Analiza dokładności dla kryterium Topografia

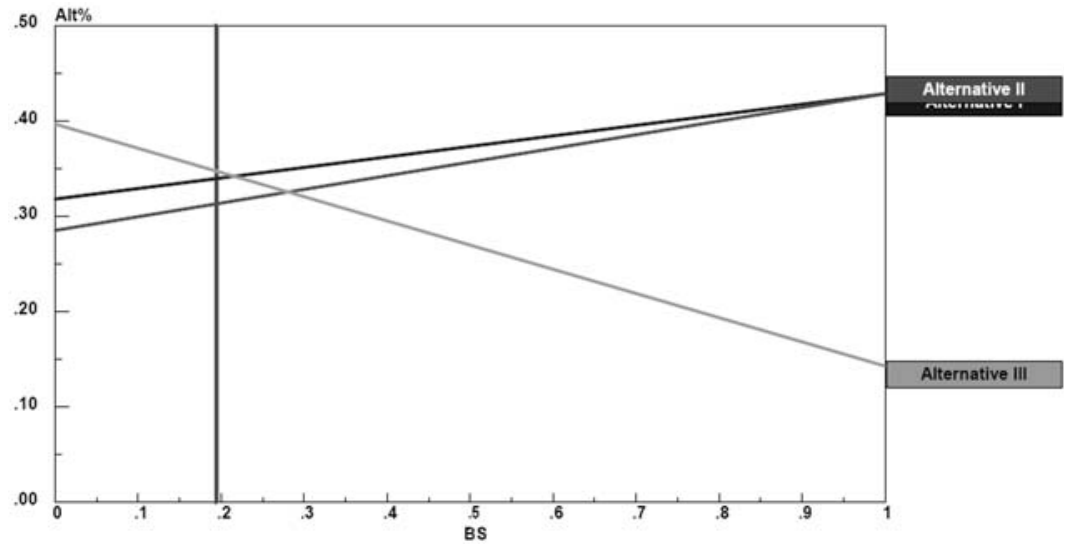

Fig. 6. Gradient sensitivity analysis for borrow - Source criterion

Rys. 6. Analiza dokładności dla kryterium Zasoby 


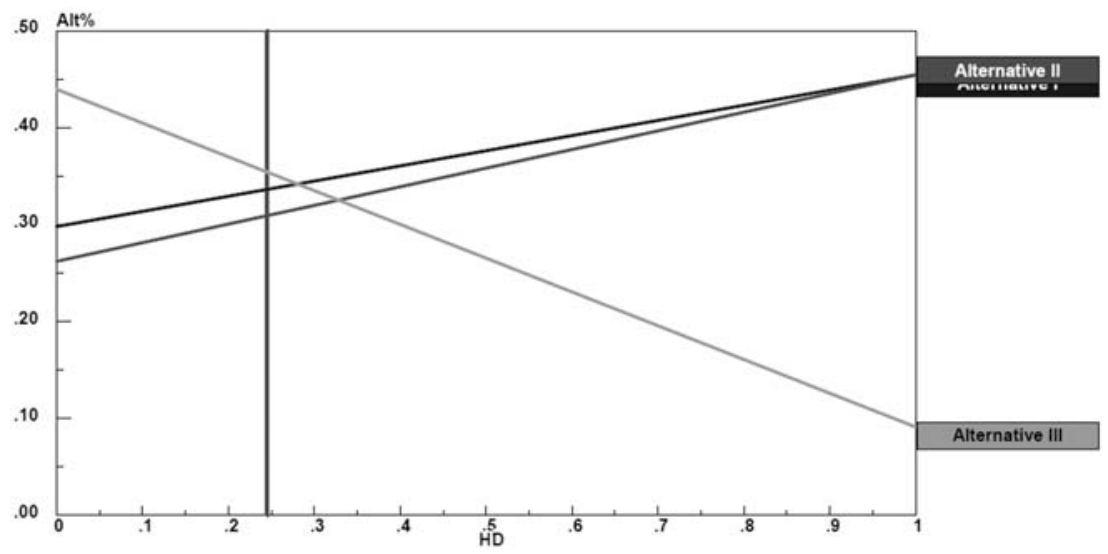

Fig. 7. Gradient sensitivity analysis for haulage Distance criterion

Rys. 7. Analiza dokładności dla kryterium Odległość

\section{Conclusions}

Selecting an appropriate location for the construction of a heap leaching facility to recover copper from ore oxides is of utmost importance. Taking advantage of multi-criteria decision making techniques is unavoidable because of the number of criteria influencing this decision. This study made use of the analytical hierarchical process (AHP) and carried out an alternative evaluation based on the results of the surveying, underground water, and environmental studies as well as expert perspectives. It is obvious that in making a decision for any heap leaching pad site, the weight and relative importance of the criteria will be quite different from the examples used in this research. It is therefore necessary that evaluations be carried out separately based on the existing conditions of specific factories. In this research, topography, hydrology, hydrogeology, geology, haulage distance, barrow sources, surrounding structures, and geotechnical criteria were considered. Evaluations were carried out using the AHP model.

\section{Acknowledgment}

The authors are indebted to Engineer Habibian from the Ian National Copper Company, Dr Rafia from Kavoshgaran Consulting Engineers, and Engineers M. Zamani and V. Rafiee from Ariafaradis Consulting Engineers for their sincere help and consultation. 


\section{REFERENCES}

Expert Choice, 2000 - Quick start guide \& tutorials: User's manual, PA: Expert Choice Inc., Pittsburgh.

Giroud et el. 2001 - Giroud J.P., Zoren berg J.G., Z ha o A., 2001 - Hydraulic design of geosynthetic and granular liquid collection layers. Geosynthetics International, pp. 285-380.

Hos s e in ali F., A le sh ei kh A.A., 2008 - Weighting spatial information in GIS for copper mining exploration, American Journal of Applied Sciences, Vol. 5, pp. 1187-1198.

Kampf et el. 2002 - Kampf S.K., S a lazar M., Tylor S.W., 2002 - Preliminary investigation of effluent drainage from mining heap leach facilities. Vadose Zone Journal, Vol. 1, pp. 186-196.

KarimiNasab et al. 2007 - KarimiNas ab S., Hojat A., MollaeiFard M.R., 2007 - Technical Factors for Selecting Optimum Heap Leach Pad Sites. Engineering \& Mining Journal, Vol. 208, pp. 54-59.

Lee et al. 2008 - L e e A.H.I., Chen W.C., C h ang C.J., 2008 - A fuzzy AHP and BSC approach for evaluating performance of IT department in the manufacturing industry in Taiwan. Expert Systems with Applications, Vol. 34, pp. 96-107.

Mahmoodzadeh et al. 2007 - Mahmoodzadeh S., Shahrabi J., P ariazar M., 2007 - Project selection by using fuzzy AHP and TOPSIS technique. International Journal of Human and Social Sciences, Vol. 30, pp. 333-338

Majdi et al. 2007 - Majdi A., Amini M., Karimi-Nas ab S., 2007 - Adequate drainage system design for heap leaching structures. Journal of Hazardous Material, pp. 288-296.

Majdi et al. 2009 - Majdi A., Amini M., Amini Chermahini A., 2009 - An investigation on mechanism of acid drain in heap leaching structures. Journal of Hazardous Material, Vol. 165. 1098-1108.

Peniwati K., 2007 - Criteria for evaluating group decision making methods. Mathematical and Computer Modelling, Vol. 46, pp. 935-947.

S a a ty T.L., Lu is V., 1991 - Prediction, projection and forecasting. s. 1. Kluwer Academic Publishers. p. 251.

S a ty T.L., 1980 - The analytic hierarchy process: Planning, priority setting, resource allocation. New York: McGraw-Hill.

S a a ty T.L., 1990 - How to mark a decision: the analytic hierarchy process. European Journal of Operational Research, Vol. 48, pp. 9-26.

S a aty T.L., 2000 - The Fundamentals of Decision Making and Priority Theory with the Analytic Hierarchy Process. s. 1, RWS Publication. p. 478.

Smith M.E., Zhao A., 2004 - Drainage net for improved service and cost reduction in heap leaching. GRF Engineering Solution Magazine, pp. 1-8.

Thiel R.T., Smith M.E., 2004 - State of the practice review of heap leach pad design issues. Geotextiles and Geomembranes, Vol. 22, pp. 555-568.

OPTYMALNY WYBÓR LOKALIZACJI STRUKTUR LUGOWANIA HALDY ZA POMOCA ANALIZY HIERARCHICZNEJ (STUDIUM PRZYPADKU: HALDA (SKLADOWISKO) TAFT, IRAN)

\section{Słowa kluczowe}

Wymywanie hałdy, kryterium oceny, optymalne miejsce, AHP

\section{Streszczenie}

Lokalizacja składowiska odpadów z procesów hydrometalurgicznych ma bardzo duży wpływ na koszty jego budowy i ryzyka związane ze środowiskiem. Wybór miejsc ługowania hałdy zależy od różnych parametrów technicznych (topograficznych, hydrologicznych, hydrogeologicznych i innych) oraz od uwarunkowań ekonomicznych i ekologicznych. W wielu przypadkach wybór optymalnych miejsc ługowania hałdy dokonywany jest z uwzględnieniem szeregu kryteriów za pomocą metod ELECTRE, TOPSIS i AHP. W artykule, w pierwszej kolejności określono kryteria do lokalizacji miejsc ługowania (o charakterze technicznym, finansowym i środo- 
wiskowym) i zbadano ich wpływ na wybór lokalizacji miejsc ługowania. Następnie korzystając z metody AHP problem decyzyjny rozpatrywano na trzech poziomach, wykorzystując oprogramowanie „Expert Choice”. W celu sprawdzenia metody wybrano hałdę w okolicy Taft, prowincji Yazd w Iranie. Analiza wrażliwości, która bada reakcję całego przedsięwzięcia została przeprowadzona dla głównych kryteriów technicznych, ekonomicznych i środowiskowych.

OPTIMAL SITE SELECTION FOR HEAP LEACHING STRUCTURES BY THE ANALYTIC HIERARCHY PROCESS (CASE STUDY: TAFT HEAP LEACHING STRUCTURE, IRAN)

$$
\text { Key words }
$$

Heap leaching, assessment criterion, optimum site, AHP

\section{Abstract}

In hydrometallurgical projects, the heap location greatly affects construction costs and environmental hazards. Heap leach pad site selection depends on different technical parameters (topographical, borrow sources, hydrological, hydro-geological, etc.) and other financial and environmental factors. In many situations, there are some proposed sites with different parameters, and it is necessary that the optimum heap leach pad site be selected with the help of multi-criteria decision making methods such as ELECTRE, TOPSIS, and AHP. In this paper, we have first studied the heap leach pad site selection criteria (technical, financial, and environmental) and their effects on the selection of the location of the heap leaching structures. Then, using the AHP method, the decision making problem was hierarchically structured at three levels. For analysis, use was made of the "Expert Choice" software. To check the practicality of the method, an appropriate site for the construction of the leaching heap was selected at the Taft area, Yazd province, Iran. Finally, sensitivity analysis exploring the overall priority of alternatives to changes in the relative synthesis value of each criterion was carried out for the main technical, economic, and environmental criteria. 
